UDC 378:331.5

JEL Classification: 123, J61

http://doi.org/10.21272/mmi.2019.1-07

\title{
Zoltan Bartha,
}

Ph.D., Associate Professor, University of Miskolc, Hungary

Andrea S. Gubik,

Ph.D., Associate Professor, University of Miskolc, Hungary

Gabor Rethi,

Ph.D., Budapest Business School, Hungary

\section{MANAGEMENT OF INNOVATIONS IN HUNGARIAN HEIS: ENHANCING THE ERASMUS MOBILITY PROGRAMME}

Abstract. The number of outgoing Erasmus students had been on the rise in Hungary between 1998 and 2012 when it reached the European mean. Following that year the numbers started to decline, creating an ever-increasing gap between the actual mobility numbers, and the quotas that the country had financial support for. Although some Hungarian institutions (e.g. the universities represented by the authors) are more affected than others, the trend is similar throughout the country. The goal of this study is to shed light on the main mobility barriers and to suggest some changes that can help in overcoming them. The study is based on a questionnaire conducted in February 2016 on all students enrolled at the University of Miskolc. A total of 225 answers were recorded. The binomial logistic regression analysis conducted by us shows that the most important barriers are the following: students' familiarity with the Erasmus programme and the staff responsible for it; international experience/familiarity with the international environment; foreign language skills; fear from the credit transfer mechanism; study level. Our suggestions to overcome these barriers are the following: better communication and involvement could familiarize students with Erasmus opportunities; improvements of services could help to overcome language deficiencies and credit transfer problems, and foreign study trips and international summer schools could provide them with important international experience. These suggestions would be relatively easy to implement, however, currently they are hindered by the universities' lack of financial resources, and also by the lack of clear strategy and commitment to Erasmus goals. Although the survey was conducted among Miskolc students, our findings may bring valuable insights to other Eastern European Universities as well that aim to intensify international student mobility.

Keywords: Erasmus, innovation in education, management in education, student mobility, student.

Introduction. There are a number of European and national targets that seek to strengthen the university students' international mobility for studying. Although they are only preliminary objectives, there is no doubt that they will soon appear among the performance indicators of universities, and this will have an impact on the external evaluation and funding of universities.

The Leuven Declaration (2009) recognizes the internationalization of higher education institutions as well as the increasing mobility of researchers, educators and students. According to its objective, in 2020, at least $20 \%$ of graduate students in the European Higher Education Area must have foreign study or training experience. Accordingly, the Ministry of Human Resources aimed at increasing the proportion of students who graduated from higher education in Hungary by 2023 from 10\% to 20\% (Palkovics, 2016) who participated in foreign studies or internships during their studies.

In addition to the shrinking resources, tutoring and employee mobility grants can be one of the most important means of creating and maintaining international relationships. In 2016 the Hungarian higher education had a budget of EUR 15 million for the implementation of Erasmus mobility, most of which supported student mobility grants. This amount can increase up to EUR 25 million by 2020 (Bokodi, 2016), but it is essential to increase student mobility activity.

At present, approximately $2 \%$ of Miskolc graduates have foreign training or study experience despite the fact that in the Institutional Development Plan of the University of Miskolc adopted in 2016, the

Cite as: Bartha, Z., Gubik, A., S., \& Rethi, G. (2019). Management of Innovations in Hungarian HEls: Enhancing the Erasmus Mobility Programme. Marketing and Management of Innovations, 1, 84-95. http://doi.org/10.21272/mmi.2019.1-07 
Z. Bartha, A. S. Gubik, G. Rethi. Management of Innovations in Hungarian HEls: Enhancing the Erasmus Mobility Programme

emphasis is on enhancing student mobility, including Erasmus mobility. Our survey was launched in early 2016 to explore obstacles to the international mobility of students and to enhance their mobility activity. The survey was extended to all students at the University of Miskolc, but we also asked the instructors who have considerable knowledge in this area.

Literature review. Promoting mobility within Europe was one of the six key objectives of the Bologna Declaration (1999). In a statement that underscores the European Higher Education Area, the signatories have committed themselves to the comparable diplomas, separation of the undergraduate and master courses, the single credit system, quality assurance, the European dimension of higher education and the mobility of students and trainers in Europe. Two years later, Prague Communication (2001) supplemented the original objectives with lifelong learning, involving students as a partner and enhancing the competitiveness of the European higher education area. The 1999 declaration was signed by 29 European countries, and now there are 48 members in the European Higher Education Area.

While the expansion of membership suggests that the initiative is a success story, many key issues are still unclear. It was clear at the outset that the evolution of the European Higher Education Area was primarily determined by the interests of the parties concerned, with particular emphasis on regional clashes (Lavdas, et al., 2006). It is a regrettable problem that standardization, which is indispensable for anti-friction operation, strongly violates the Humboldt principles of university autonomy (Arouet, 2009; Haukland, 2014). The limitation of the initial training period to three years received considerable critiques, but empirical results show that training courses for the Bologna system were more popular among students (Cardoso 2008). Some empirical results suggest that reforms to create a European Higher Education Area have brought about changes in universities that have improved student satisfaction (Fernandez-Sainz, et al., 2016).

The priorities of the European Higher Education Area have been set with the unencrypted aim of enhancing the interoperability of higher education, which is beneficial for the mobility of the European workforce. Empirical researches seem to confirm these calculations. Parey and Waldinger (2011) examined the German students participating in the Erasmus program between 1989 and 2005. They found that the students were twice as likely to work abroad as their student-mates without Erasmus experience. It is commonly acknowledged among researchers that the Erasmus program improves students' chances of learning and is often referred to as intercultural experience, and foreign language competencies due to mobility. Yucelsin-Tas (2013) examined Turkish students but pointed out that $87 \%$ of Erasmus students had serious language difficulties, so Erasmus's foreign language skills development is questionable.

Although the full range of higher education alternatives to internationalization is increasingly referred to mobility for training (Henard, et al., 2012), our study focuses on the mobility for studying dimension of Erasmus in the EHEA.

Student mobility is one of the most visible elements of internationalization in education (Byram, Dervin, 2009). The main aim is to strengthen and raise awareness of European identity and citizenship, promote European cultural diversity and multiculturalism (King and Ruiz-Gelices, 2003, Mitchell, 2012, 2015, Papatsiba, 2006) and, on the other hand, to make more efficient use of skilled workers with foreign experience (Diosi, 1998). Foreign studies have considerable advantages in the student's learning process and the development of their competences (Bracht et al., 2006; Gonzalez, et al., 2010):

- obtaining theoretical knowledge that is not provided at the sending institution or at a lower level;

- social, economic and cultural experiences can be gained in the host country;

- studies can be successfully conducted in cross-border disciplines, professions (e.g. international law, international business, etc.);

- internationally comparable views can be learned;

- the vision can be widened and shaded through experiences gained from knowing the different cultures; 
Z. Bartha, A. S. Gubik, G. Rethi. Management of Innovations in Hungarian HEls: Enhancing the Erasmus Mobility Programme

- intercultural communication techniques can be learnt, and intercultural competencies can be developed.

Empirical tests for the two identified purposes of Erasmus mobility are found in the literature. Researchers have different views on the first one, strengthening the European identity. Previous studies (Kuhn, 2012) have not found significant «Erasmus impact» in the context of European identity. According to Sigalas (2010) and Wilson (2011), the impact of mobility on developing a European identity is exaggerated. By contrast, Mitchell (2015), among 1729 students from 28 universities in 6 countries, concluded that participation in the Erasmus exchange program has a significant and positive relationship with the identification of European identity and European identity. Cross-border activities, conscious mobility programs and plans have contributed to Hungary's entry into countries in which the acquisition of foreign experience for a shorter or longer period is becoming more and more self-evident among young people (Kincses and Redei, 2010, L. Redei, 2006).

Due to the scale of the interview (56 733 students were asked), the most recent issue of «the Erasmus impact study» (Brandenburg, 2014) is certainly providing the most complete picture about the impact of Erasmus mobility on the labour market. The results have shown that participation in international mobility has increased the chances of student placement, including a greater likelihood of later foreign placement. Better positions have been achieved and more advancement has been reported by students participating in mobility compared to non-customers. Further studies on this subject reinforced the same results. Bryla (2015) asked workers with many years of experience in their previous mobility activities (in 2006, in the 2006 mobility report, in the mobility program), who confirmed the positive impact of mobility on career paths. Engel (2010) also notes that students from Central and Eastern European countries benefited more from mobility than their Western counterparts.

According to King and Ruiz-Gelices (2003), academic literature rarely identifies student mobility as a migration phenomenon. There are, however, more popular routes on the «mobility map», which are usually drawn up along social, economic and historical grounds. Teichler (2011) has studied student mobility patterns for the past decade in 32 program countries. According to this study, the main destinations for student mobility at the time of the survey were the United Kingdom, Germany and France; the two-thirds of the students selected these three countries.

Also, according to this study, up to $10-15 \%$ of students in some EU Member States participated in foreign mobility for longer or shorter periods. Mobility activity increased by more than $50 \%$ between 1998 1999 and 2006-2007. In the 2006-2007 academic year, incoming student numbers exceeded 1.5 million and more than half of these students came from non-EU countries. In the case of outgoing students, lower numbers can be reported during this period, and the number of students has not reached half of the incoming students. There is also an increase in outgoing mobility between the years 1998-1999 and 20062007 , but far less than in the case of incoming students. This study distinguishes between full-time studies and part-time training (credit for mobility). It evaluates the latter on the basis of the Erasmus program data, and during the period under review, Erasmus accounted for about one-tenth of total mobility.

In mobility trends, there are many obstacles that can be identified in almost all countries (Souto-Otero et al., Teichler, 1996, Teichler and Janson, 2007). These are lack of information, low motivation for mobility, inadequate financial support, low level of foreign language knowledge, low time or inappropriate opportunities for international students in new curricula and programs, concerns about the quality of mobility experience, legal obstacles (such as visa, immigration rules, work permits) and the challenges of achieving performance. Teichler et al. (2011) identified increased financial support, more and more harmonized study programs and personal support as elements supporting mobility.

In Hungary in the 1990s, 2-5\% of students in higher education participated in foreign mobility (L. Redei, 2006; Rivza, Teichler, 2007; Teichler, 1996, 2004). In Hungary's mid-2000s, Honvari (2012) noted that there was a discrepancy between the popularity and the actual country of travel. Intensive language 
Z. Bartha, A. S. Gubik, G. Rethi. Management of Innovations in Hungarian HEls: Enhancing the Erasmus Mobility Programme

learning and existing language skills play a major role in initiating foreign studies and other mobility. According to Honor (2012), students primarily chose a country for non-learning purposes, so they did not study or studied abroad or improved their cultural competencies. (In the case of the learning target they did not typically consider the knowledge that was formally acquired.) It is worth distinguishing the position of the Hungarians beyond the borders, as their mobility and migration activities are obviously not motivated by professional development alone (Eross et al. Migration is also heavily influenced by border regions and income relationships as well as by social-family relations (Kincses, 2009, Kincses, Redei, 2010).

It is also clear that foreign experiences have a self-motivating process: it is easier for those who have previously participated in similar activities to undertake mobility. This is true even if we know that migration intentions do not yet mean actual realization. On the basis of Eurostudent V's Hungarian database, Kiss (2014) points out that the socio-economic status (the perceived and real economic situation, the educational level of parents, etc.) influences the international mobility intent.

Methods. In February 2016, we launched a survey among all students of the University of Miskolc to explore the causes of low student mobility. The research concentrated on the mobility wing of the Erasmus+ program, including the mobility of the program countries (EU Member States, Iceland, Liechtenstein, Macedonia, Norway and Turkey) (hereafter: Traditional Erasmus). Regarding both availability and budget, traditional Erasmus is the most significant Erasmus pillar in Hungarian higher education. An online questionnaire powered by the Evasys system was used.

Table 1. The sample's distribution among faculties

\begin{tabular}{|c|c|c|}
\hline Faculty & No. & distribution (\%) \\
\hline Faculty of Law (FoL) & 31 & 13.8 \\
\hline Bartok Bela Music Institute (BBMI) & 3 & 1.3 \\
\hline Faculty of Arts (FoA) & 42 & 18.7 \\
\hline Faculty of Healthcare (FoH) & 15 & 6.7 \\
\hline Faculty of Mechanical Engineering and Informatics (FoMEI) & 60 & 26.7 \\
\hline Faculty of Economics (FoE) & 47 & 20.9 \\
\hline Faculty of Materials Science and Engineering (FoMSE) & 10 & 4.4 \\
\hline Faculty of Earth Science and Engineering (FoESE) & 17 & 7.6 \\
\hline Total & 225 & 100.0 \\
\hline
\end{tabular}

Source: compiled by the authors.

The online questionnaire available in the Evasys system was sent to all university students (more than 8,000 people). A total of 225 evaluable responses came back. The response rate is low, and the questionnaire is filled in with a higher rate of Erasmus + mobility students.

According to training levels, a significant proportion of students (61.8\%) undergo basic studies, $31.6 \%$ of students study at a master's level. In the sample, $9 \mathrm{PhD}$ students and 6 higher education vocational students were enrolled. According to the training format, the majority of students are the full-time and public-funded student (55.1\%). $22.7 \%$ of respondents are full-time and tuition-paid, $13.3 \%$ of them are part-time and tuition-paid, and $8.9 \%$ of them are part-time and state-funded. $60 \%$ of students in the sample are women.

Our colleagues made a personal interview with fifteen students. The interviewees were selected in a way to involve several levels of training (basic and master training, doctoral training) and as many faculties as possible (FoL, BBMI, FoMEI, FoE, FoMSE and FoESE). An interviewee could be those who have filled out the survey questionnaire and indicated that he/she would have the willingness to attend the interview or a student who previously won an Erasmus scholarship but cancelled the trip. In addition to student interviews, we also interviewed five university lecturers. Our interviewees represented the faculties of 
Z. Bartha, A. S. Gubik, G. Rethi. Management of Innovations in Hungarian HEls: Enhancing the Erasmus Mobility Programme

engineering and social sciences. All of them had many years of experience in internationalization as Erasmus+ Coordinator or Head of International Affairs.

$16.4 \%$ of the interviewed students participated in the mobility program. FoE students are the most active, $29.8 \%$ of them participated in an international mobility program. This is followed by FoL $(19.4 \%)$, FoA (16.7\%) and FoMEI (11.7\%).

We noticed differences in the recognition of the Erasmus+ mobility opportunity by faculties (Table 2). The students of FoE and FoL are the most well-informed, least of all FoH and FoMEI students. There are bigger differences in the recognition of the Erasmus+ faculty coordinator. Here too, FoE is leading, $72.3 \%$ of the students are familiar with the Faculty Coordinator, but the FoH and FoMEI students $(26.7 \%)$ are illiterate. The worst statistics were obtained from the central Erasmus+ Administration. FoE and FoL perform relatively well, with $55.3 \%$ and $38.7 \%$ of students giving a positive response.

Table 2. Rate of knowledge about Erasmus+ mobility possibilities, and about faculty and central administration

\begin{tabular}{|c|c|c|c|c|}
\hline \multirow{2}{*}{ Faculty } & \multirow{2}{*}{$\begin{array}{c}\text { Number of } \\
\text { respondents }\end{array}$} & $\begin{array}{c}|c| \\
\text { the Erasmus+ mobility } \\
\text { opportunities? }\end{array}$ & $\begin{array}{c}\text { Do you know... } \\
\text { the Faculty Erasmus+ } \\
\text { Coordinator? }\end{array}$ & $\begin{array}{c}\text { the central Erasmus+ } \\
\text { Administration? }\end{array}$ \\
\hline FoL & 31 & $71.0 \%$ & $54.8 \%$ & $38.7 \%$ \\
\hline FoA & 42 & $61.9 \%$ & $31.0 \%$ & $35.7 \%$ \\
\hline FoH & 15 & $53.3 \%$ & $26.7 \%$ & $13.3 \%$ \\
\hline FoMEl & 60 & $55.0 \%$ & $26.7 \%$ & $28.3 \%$ \\
\hline FoE & 47 & $83.0 \%$ & $72.3 \%$ & $55.3 \%$ \\
\hline FoMSE & 10 & $60.0 \%$ & $50.0 \%$ & $20.0 \%$ \\
\hline FoESE & 17 & $58.8 \%$ & $64.7 \%$ & $23.5 \%$ \\
\hline
\end{tabular}

Source: own calculations.

$65 \%$ of students who have not yet joined the mobility program are planning international mobility during their studies. The figures make it clear that the student's interest is also high in the faculties where the number of students who joined Erasmus is low.

According to the training level, the graduate students are the most active, $23.9 \%$ of them have already participated in a mobility program. The activity of undergraduate students is below average, only $12.2 \%$ of them were responding "yes» to the question. The activity of the PhD students completing the questionnaire is high $(22.2 \%)$ and the activity of higher education vocational students is average, but in both of the latter casescases, there is too little answer to draw conclusions from a wider range of students. The answers confirm that the MSc/MA and PhD students are most likely to be the potential target group of Erasmus+ programs at the training level. The form of funding is also decisive in the development of international mobility. The mobility of state-funded students exceeds the tuition-paying students. In the former case, $18.1 \%$ of respondents, in the latter case, $13.6 \%$ of respondents answered "yes» to the question. For students with a tuition fee, it is more difficult to keep the training time, which is confirmed later by further questions. One of the major influences of Erasmus+ mobility seems to be whether the student has been abroad for other purposes (international experiences/familiarity with the international environment). There was a significant correlation between the number of previous trips abroad and the probability of using Erasmus mobility (Cramer's $V=0.249 ; p=0.01$ ). The more foreign trips interviewed students were, the greater share of them participated in student mobility.

Results. According to the respondent's opinion, the most important aspect of mobility decision-making is the rate of scholarship and the cost of living. This is followed by the security of the host country and the adequate course offer of the host university. Based on the answers, the least important aspect is the distance and the climate (Figure 1). 
Z. Bartha, A. S. Gubik, G. Rethi. Management of Innovations in Hungarian HEls: Enhancing the Erasmus Mobility Programme

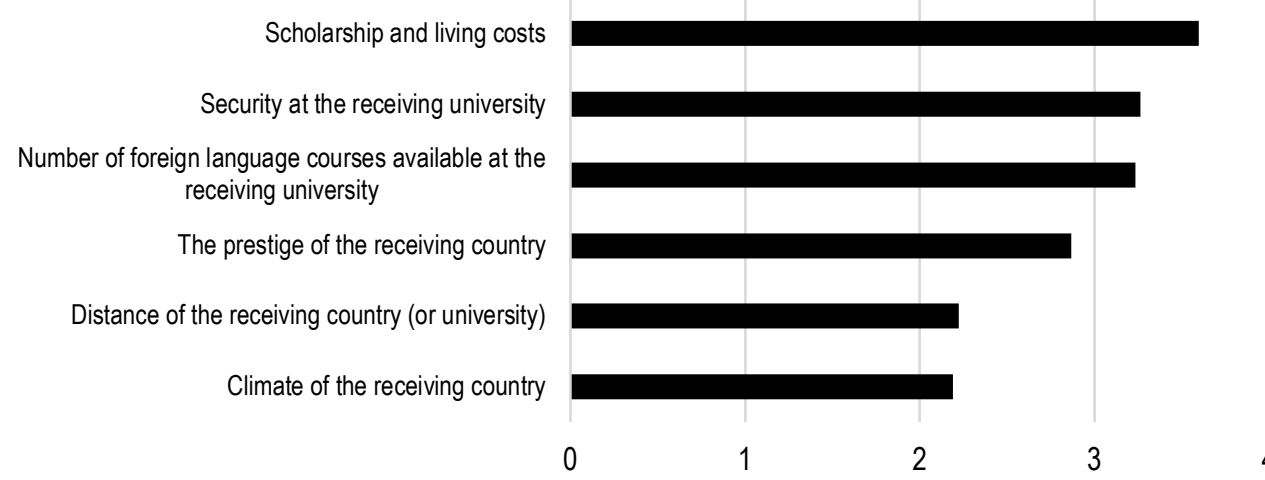

Source: own calculations.

Figure 1. Drivers of the mobility decision

Among the factors that creating uncertainty about mobility is financial reasons in the first place. This is followed by educational reasons, such as the fear of slipping in studies and the fear of recognition of subjects. The factors studied were primarily evaluated with high scores by students who did not participate in international mobility. There are significant differences between Erasmus+ participants and nonparticipants in a number of factors (Figure 2).

fear of not being able to meaningfully convert credits earned abroad

$$
\begin{array}{r}
\text { fear of high material costs } \\
\text { fear of being alone abroad } \\
\text { fear of delay of studies } \\
\text { job at home } \\
\text { English language skills }
\end{array}
$$
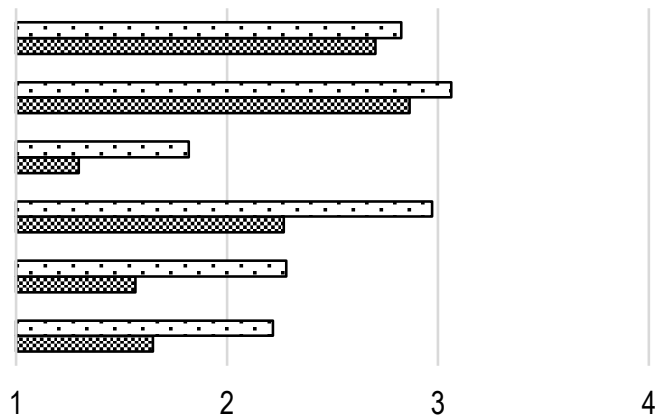

口have not participated

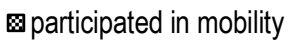

Source: own calculations.

\section{Figure 2. Concerns about Erasmus mobility}

The influencing factors show divergences by faculties, but only in the case of slipping in studies, we found a significant correlation ( $E$ ta $=0.243, p=0.06$ ). The students of FoMSE, FoL and FoMEl appreciate the importance of this factor above the average; the students of FoA consider it as the least important. The majority do not see their language proficiency as problematic; only 40 felt that it greatly reduced their willingness for mobility. Most respondents $(41.8 \%)$ do not see this as a barrier. There are also deviations from the training level. Undergraduate students appreciate more the role of the individual factors than the master students do. However, significant differences can only be observed in the case of language proficiency and in the case of subjects studied abroad. 
Z. Bartha, A. S. Gubik, G. Rethi. Management of Innovations in Hungarian HEls: Enhancing the Erasmus Mobility Programme

The combined explanatory power of the previously analysed influence factors was studied by a binomial logistic regression model. The virtue of the model is that it can be applied to low-level dependent variables, in our case, «Have you already participated in the Erasmus+ Mobility Program organised by the University of Miskolc earlier? (Or right now?)», where «yes» and «no» responses were given. Independent variables can be both continuous and categorical variables. In our case, we started the analysis with the following variables:

1. Where do you study? (faculty).

2. What training level? (level).

3. What kind of training do you study? (form).

4. Do you know the Faculty Erasmus+ Coordinator? Do you know whom to contact personally if you need help? (coord).

5. How many times did you go abroad for the last five years? (abroad).

6. The level of foreign language (especially English) (foreign language).

7. Fear of slipping in studies (sliding).

8. Fear of independence, loneliness in abroad (self-reliance).

9. Fear of the degree of scholarship, financial insecurity (financial).

10. Fear of domestic recognition of subjects studied abroad (recognition).

The variables were introduced to the model by way of the forward method, in which the model was added step by step by adding significant variables based on conditional statistics. Table 3 shows the variables entering the model and the order of entry, indicating the significance levels of each variable.

Table 3. Influencing factors of international mobility

\begin{tabular}{|c|c|c|c|c|c|c|c|}
\hline \multicolumn{2}{|c|}{} & B & S.E. & Wald & df & Sig. & Exp(B) \\
\hline \multirow{3}{*}{ Step 1a } & coordinator & 3.477 & .743 & 21.899 & 1 & .000 & 32.348 \\
\cline { 2 - 8 } & Constant & -2.842 & .826 & 11.826 & 1 & .001 & .058 \\
\hline \multirow{3}{*}{ Step 2b b } & coordinator & 3.356 & .747 & 20.158 & 1 & .000 & 28.670 \\
\cline { 2 - 8 } & prev.exp & -1.001 & .365 & 7.520 & 1 & .006 & .368 \\
\cline { 2 - 8 } & Constant & -.367 & 1.211 & .092 & 1 & .762 & .693 \\
\hline \multirow{4}{*}{ Step 3c c } & coordinator & 3.401 & .753 & 20.392 & 1 & .000 & 29.991 \\
\cline { 2 - 8 } & prev.exp & -.926 & .373 & 6.158 & 1 & .013 & .396 \\
\cline { 2 - 8 } & delay.study & .400 & .177 & 5.084 & 1 & .024 & 1.491 \\
\cline { 2 - 8 } & Constant & -1.626 & 1.343 & 1.465 & 1 & .226 & .197 \\
\hline \multirow{5}{*}{ Step 4d d } & coordinator & 3.443 & .760 & 20.539 & 1 & .000 & 31.272 \\
\cline { 2 - 8 } & prev.exp & -.829 & .385 & 4.632 & 1 & .031 & .437 \\
\cline { 2 - 8 } & foreign.lan & .446 & .220 & 4.087 & 1 & .043 & 1.561 \\
\cline { 2 - 8 } & delay.study & .372 & .180 & 4.286 & 1 & .038 & 1.451 \\
\cline { 2 - 8 } & Constant & -2.678 & 1.470 & 3.321 & 1 & .068 & .069 \\
\hline & coordinator & 3.756 & .857 & 19.222 & 1 & .000 & 42.774 \\
\cline { 2 - 8 } & prev.exp & -.818 & .392 & 4.353 & 1 & .037 & .441 \\
\cline { 2 - 8 } & foreign.lan & .508 & .232 & 4.775 & 1 & .029 & 1.662 \\
\cline { 2 - 7 } & delay.study & .373 & .182 & 4.203 & 1 & .040 & 1.452 \\
\cline { 2 - 8 } & level & & & 5.305 & 3 & .151 & \\
\cline { 2 - 7 } & level(BA/BSc) & 3.056 & 1.398 & 4.781 & 1 & .029 & 21.253 \\
\cline { 2 - 7 } & levelMA/MSc) & 2.600 & 1.419 & 3.357 & 1 & .067 & 13.460 \\
\cline { 2 - 7 } & level(PhD) & 2.884 & 1.646 & 3.070 & 1 & .080 & 17.878 \\
\cline { 2 - 7 } & Constant & -5.974 & 2.263 & 6.967 & 1 & .008 & .003 \\
\hline
\end{tabular}

Source: own calculations conducted with SPSS 14. 
Z. Bartha, A. S. Gubik, G. Rethi. Management of Innovations in Hungarian HEls: Enhancing the Erasmus Mobility Programme

The explanatory power of the model is $46.6 \%$ (Nagelkerke $\mathrm{R}^{2}=0.466$ ). The significance levels of Wald statistics convinced us that the inclusion of individual variables in the model is justified because they represent a significant part of the evolution of international mobility (i.e., while maintaining the other variables, their explanatory power remains significant). The odds ratio - Exp (B) - shows how many times the mobility would increase if the student came from one category of the variable. According to the Classification Table (Table 4), the resulting rate is $88 \%$, i.e. it is successful in $88 \%$ based on the model.

Table 4. Classification table showing the predictive power of the model

\begin{tabular}{|c|c|c|c|c|c|}
\hline & \multirow{3}{*}{\multicolumn{2}{|c|}{ Observed }} & \multicolumn{3}{|c|}{ Predicted } \\
\hline & & & \multicolumn{2}{|c|}{$\begin{array}{l}\text { Have participated in the } \\
\text { Erasmus+ mobility program } \\
\text { (before or right now)? }\end{array}$} & \multirow[t]{2}{*}{$\begin{array}{l}\text { Percentage } \\
\text { Correct }\end{array}$} \\
\hline & & & Yes & No & \\
\hline \multirow{3}{*}{ Step 5} & \multirow{2}{*}{$\begin{array}{l}\text { Have participated in the Erasmus+ } \\
\text { mobility program (before or right now)? }\end{array}$} & Yes & 17 & 20 & 45.9 \\
\hline & & No & 7 & 181 & 96.3 \\
\hline & \multicolumn{2}{|l|}{ Overall Percentage } & & & 88.0 \\
\hline
\end{tabular}

Source: own calculations.

On the basis of the results, the degree of involvement in international mobility is significantly determined by the extent to which the student is informed about the opportunities and who can provide meaningful information and assistance for them. At the same time, it is the fastest and easiest way to intervene in order to encourage mobility. It is also important whether the student has international experience; how many times he has been abroad. Likewise, the level of language proficiency is decisive in the decision. The former factor can give you the courage to help make a positive decision, and the right language knowledge is the elemental influence of mobility. International experiences can be partially supplemented by joint study visits and participation in summer schools. Fear of sliding in studies also affects the international activity of students. Communication and the co-operation between the faculties can also be helpful in the credit recognition process. The most recent explanatory variable is the level of training. The regression model also provides underlying results. The reference category is the higher vocational training, and the higher training levels are compared to it. The probability of international mobility increases 21.25 times in the BSc/BA level and further increases in the MSc/MA and PhD levels (13 and 17 times greater chances of mobility compared to higher vocational education).

The model reveals that the differences between the faculties are not primarily due to belonging to a given faculty, but the characteristic variances found in the four factors mentioned and it leads to different activity.

Conclusion. To overcome the obstacles mentioned in the study, Erasmus Office, Erasmus Coordinators, and Erasmus Student Network (ESN) have an important role. Most of the tasks focus on three areas, (1) more effective communication, (2) improved service quality, (3) improved co-operation and effective involvement of stakeholders.

In the communication of the university Erasmus organization, it has to strengthen elements that better reach the less conscious students. Efforts should be made for students to appear on events outside the organization (job fair, mobility expo, Miskolc University Days, professional days). Focus on communication channels commonly used by young people (social networking sites, video sharing). According to surveys, primary targets are master students, so in communication, they must also be a priority group. Since livelihood costs are the main cause of uncertainty for potential applicants, it is essential to provide accurate information about the cost of living for each target country and target area as well as the possible sources of additional funding. 
Z. Bartha, A. S. Gubik, G. Rethi. Management of Innovations in Hungarian HEls: Enhancing the Erasmus Mobility Programme

Two proposals have been formulated to improve the services provided to Erasmus applicants. An important barrier is the lack of language skills or the level of knowledge of the language, so in cooperation with the Foreign Language Education Centre, it is recommended to introduce the pre-language screening and intensive language courses for those who need to improve their language skills. Pre-screening should also work as a counselling to indicate to students' which countries or universities are those to which it is worth to apply, taking into consideration their level of language skills.

Based on the answers it was apparent that there was a great need to provide further assistance in managing administrative matters (booking, organizing travel, selecting foreign subjects). One form of this is to build a database of frequently asked questions and to create template documents. Personal counselling involves the involvement of student mentors and trainees on the one hand, because it does not increase the number of administrative staff and on the other hand because students are more likely to turn to their partner for help.

Students' mobility activities can be enhanced by enabling them to be more effectively involved in the university Erasmus organization. The involvement of trainers and teachers who can rely on recruiting should be strengthened. On the other hand, educators should also be made aware that many students are scared of the Erasmus mobility because they may not agree with the teachers in Miskolc about the recognition of the completed course or, failing this, the method of completing the exam. It is also necessary to involve more intensively the students who have been studying abroad with Erasmus, especially in terms of recruitment and promotion, as well as information.

The regression model, based on the answers to the questionnaires, shows that the most important explanation for lower student activity is student ignorance, lack of knowledge of Erasmus opportunities, they do not know who the coordinator is and who to contact with. In order to overcome the lack of awareness, the need to strengthen the communication of Faculty Erasmus coordinators is needed. It is necessary to use more active coordinator attitudes and more direct communication channels (e.g. use of newcomers' camps and other student events for information and recruitment). The slipping in studies is a major obstacle for students with tuition fees, so the faculty coordinator is responsible for communicating that the faculty has adopted clear rules to ensure that Erasmus mobility does not go with a semester sliding and thus does not create an additional financial burden. International mobility can be communicated as a requirement for $\mathrm{PhD}$ students.

The fear of semester slams should be treated not only by improving communication but also by improving the quality of services and simplifying administrative processes. It is indispensable to build a clear and smooth credit recognition process in each faculty, which also ensures that the registration of the recognised subjects in the Neptun system takes place within a reasonable time. The introduction of the mobility window system is a task for the faculties; it means the design of an optional spectrum in which a wide range of foreign subjects can be recognised. This solution helps to avoid that the awarded scholarships can be cancelled because students have not been able to find Miskolc subjects in which the minimum required 30 credits of foreign subjects for Erasmus is recognized by the university.

It is strongly recommended for the faculty to build a network of partners much more consciously than before. This is necessary because mobility is strengthened by partners to whom the students are willing to go (geographic-cultural aspect) and where courses can be selected that is compatible with the Miskolc course structure (educational aspect). Since many students are afraid of loneliness, it is advisable to conclude partnership agreements that allow at least two students to travel concurrently.

Organizations gathering students should be involved much more than before in recruiting and communicating with outgoing students. ESN has traditionally been involved in the reception of incoming students, but the results of the survey show that encouraging fellow students and personal stories may be more effective than raising centrally generated communication to raise interest and resolve uncertainties. 
It is also desirable to activate Erasmus students in Miskolc; joint programs with local and guest students can attract more interest in Erasmus.

Author Contributions: Conceptualization Z. B.; methodology A. S. G.; software A. S. G.; validation A. S. G. and Z. B; formal analysis A. S. G.; investigation Z. B. and A. S. G.; resources A. S. G., Z. B. and G. R.; writing - original draft preparation A. S. G., Z. B. and G. R.; writing - review and editing G. R., Z. B.; visualization Z. B.; funding acquisition Z. B.

Funding. The research was funded by Erasmus+, and conducted by Zoltan Bartha, Zsolt Krajcsik, Robert Marciniak, Gabor Rethi, Andrea Safranyne Gubik and Edit Szoke. A detailed Hungarian report is available in Ter es Tarsadalom, DOI: 10.17649/TET.31.4.2886.

\section{References} 35.

Arouet, F. (2009). Competitive advantage and the new higher education regime. Entelequia. Revista Interdisciplinar, 10, $21-$

Bokodi Sz. (2016). Felsooktatasi programok helyzete a Tempus Kozalapitvanynal. Konferencia-eloadas, Miskolc-Lillafured 2016. november 8-10.

Bolognai nyilatkozat (1999). Az europai oktatasi miniszterek kozos nyilatkozata. https://media.ehea.info/file/ Ministerial_conferences/02/8/1999_Bologna_Declaration_English_553028.pdf (Accessed: 19/09/2017)

Bracht, O., Engel, C., Janson, K., Over, A., Schomburg, H., Teichler, U. (2006). The professional value of Erasmus mobility. International Centre of Higher Education Research, University of Kassel, Kassel

Brandenburg, U. (2014). The Erasmus impact study. Effects of mobility on the skills and employability of students and the internationalisation of higher education institutions. Publications Office of the European Union, Luxembourg

Bryla, P. (2015). The impact of international student mobility on subsequent employment and professional career: A large-scale survey among Polish former Erasmus students. Procedia - Social and Behavioral Sciences, 176., $633-641$. https://doi.org/10.1016/j.sbspro.2015.01.521

Byram, M., Dervin, F. (eds.). (2009). Students, staff and academic mobility in higher education. Cambridge Scholars Publishing, Cambridge

Cardoso, A. (2008). Demand for higher education programs: The impact of the Bologna process.

CESifo Economic Studies, 2., 229-247. https://doi.org/10.1093/cesifo/ifn013

Diosi P. (1998). A magyar fiatalok kulfoldi tanulasi es munkavallalasi szandekai, illetve tapasztalatai. Esely, 2, 57-65.

Engel, C. (2010). The impact of Erasmus mobility on the professional career: Empirical results of international studies on temporary student and teaching staff mobility. Belgian Journal of Geography, 4, 351-363. http://doi.org/cc9d

Eross a., Filep B., Racz K., Tatrai P., Varadi M. M., Wastl-Walter D. (2011). Tanulmanyi celu migracio, migrans elethelyzetek: vajdasagi diakok Magyarorszagon. Ter es Tarsadalom, 4., 3-19.

Fernandez-Sainz, A., Garcia-Merino, J. D., Urionabarrenetxea, S. (2016). Has the Bologna process been worthwhile? An analysis of the learning society-adapted outcome index through quantile regression. Studies in Higher Education, 9., $1579-1594$. http://doi.org/cc9f

Gonzalez, C. R., Mesanza, R. B., Mariel, P. (2010). The determinants of international student mobility flows: an empirical study on the Erasmus programme. Higher Education, 4., 413-430.

Haukland, L. (2014). The Bologna process: Between democracy and bureaucracy. Proceedings of the 10th International Academic Conference, Vienna, June 2014, 282-299.

Henard, F. Diamond, L. Roseveare D. (2012). Approaches to internationalisation and their implications for strategic management and institutional practice. OECD. https://www.oecd.org/edu/imhe/appro- aches $\% 20$ to\%20internationalisation $\% 20$ \%20final\%20-\%20web.pdf (Accessed: 19/09/2017)

Honvari J. (2012). Migracios potencial es a potencialis tanulasi migracio. Hazai hallgatok kulfoldi tanulasi szandekai. Ter es Tarsadalom, 3., 93-113.

Kincses A. (2009). A Magyarorszagon elo kulfoldiek teruleti elhelyezkedese. Ter es Tarsadalom, 1., 119-131.

Kincses A., Redei M. (2010). Centrum-periferia kerdesek a nemzetkozi migracioban. Ter es Tarsadalom, 4., 301-310. https://doi.org/10.17649/tet.24.4.1805

King, R., Ruiz-Gelices, E. (2003). International student migration and the European «year abroad»: Effects on European identity and subsequent migration behaviour. International Journal of Population Geography, 3., 229-252. http://doi.org/dqwczg

Kiss L. (2014). A nemzetkozi hallgatoi mobilitas strukturalis es tarsadalmi-gazdasagi hattertenyezoirol.

In: Eurostudent V. Kutatasi zarotanulmany. Educatio Tarsadalmi Szolgaltató Nonprofit Kft., Budapest 
Kuhn, T. (2012). Why educational exchange programmes miss their mark: Cross-border mobility, education and European identity. Journal of Common Market Studies, 6., 994-1010. http://doi.org/cc9g

L. Redei M. (2006). Tanulasi celu migracio a vilagban es itthon. Demografia, 2-3., 232-250.

Lavdas, K., Papadakis, N. Gidarakou, M. (2006). Policies and networks in the construction of the European Higher Education Area. Higher Education Management and Policy, 1., 121-131. http://doi.org/b7rgws

Leuveni Declaration (2009). http://www.ehea.info/media.ehea.info/file/2009_Leuven_Louvain-la-Neuve/06/1/Leuven_Louvainla-Neuve_Communique_April_2009_595061.pdf

Mitchell, K. (2012). Student mobility and European identity: Erasmus study as a civic experience? Journal of Contemporary European Research, 4., 490-518.

Mitchell, K. (2015). Rethinking the «Erasmus effect» on European identity. Journal of Common Market Studies, 2., 330-348 http://doi.org/cc9h

Palkovics L. (2016). A felsooktatasert felelos allamtitkar sajtotajekoztatoja a Miskolci Egyetemen a Campus Mundi programrol. http://www.uni-miskolc.hu/hirek/799/sajtotajekoztaton_mutatta_be_pal-kovics_laszlo_allamtitkar_a_campus_mundi_programot (Accessed: 19/09/2017)

Papatsiba, V. (2006). Making higher education more European through student mobility? Revisiting EU initiatives in the context of the Bologna process. Comparative Education, 1., 93-111. http://doi.org/d3wxqc

Parey, M. Waldinger, F. (2011). Studying abroad and the effect on international labour market mobility: Evidence from the introduction of Erasmus. The Economic Journal, 551., 194-222. http://doi.org/cfjvmp

Prague Communique (2001). Towards a European Higher Education Area: http://www.ehea.info/media.ehea.info/file/2001_Prague/44/2/2001_Prague_Communique_English_553442.pdf

Rivza, B., Teichler, U. (2007): The changing role of student mobility. Higher Education Policy, 4., 457-475. http://doi.org/b6c6r8

Sigalas, E. (2010). Cross-border mobility and European identity: The effectiveness of intergroup contact during the Erasmus year abroad. European Union Politics, 2., 241-265. http://doi.org/ff774w

Souto-Otero, M., Huisman, J., Beerkens, M., de Wit H., Vujic, S. (2013). Barriers to international student mobility: evidence from the Erasmus program. Educational Researcher, 2., 70-77. http://doi.org/cc9j

Teichler, U. (1996). Student mobility in the framework of Erasmus: Findings of an evaluation study.

European Journal of Education, 2., 153-179.

Teichler, U. (2004). Temporary study abroad: the life of Erasmus students. European Journal of Educa- tion, 4., 395-408. http://doi.org/bpfn56

Teichler, U., Ferencz, I., Wachter, B., Rumbley, L., Burger S. (2011). Mapping mobility in European higher education. Volume I: Overview and trends. Brussels

Teichler, U., Janson, K. (2007). The professional value of temporary study in another European country: Employment and work of former Erasmus students. Journal of Studies in International Education, 3-4., 486-495. http://doi.org/db8t4r

Varadi M. M. (2013). Migracios tortenetek, dontesek es narrativ identitas. A tanulmanyi celu migra- ciorol - maskent. Ter es Tarsadalom, 2., 96-117. https://doi.org/10.17649/tet.27.2.2520

Wilson, I. (2011). What should we expect of «Erasmus generations»? Journal of Common Market Studies, 5., 1113-1140 http://doi.org/c7dxw]

Yucelsin-Tas, Y. (2013). Problems encountered by students who went abroad as part of the Erasmus programme and suggestions for solutions. Journal of Instructional Psychology, 1-4., 81-87.

3. Барза, Ph.D., доцент, Мішкольцький Університет (Угорщина);

A. C. Губік, Ph.D., доцент, Мішкольцький Університет (Угорщина),

Г. Резі, Ph.D., Будапештська школа бізнесу (Угорщина).

Управління інноваційним розвитком 3ВО Угорщини: поширення програм мобільності Erasmus

Сучасні тенденції популяризації програм міжнародної студентської мобільності обумовлюють зростання кількості угорських студентів, які вибороли право на проходження навчання за Європейськими програмами у період з 1998 по 2012 рр. Однак, після 2012 року кількість студентів почала скорочуватись, утворюючи значний розрив між фрактичною чисельністю учасників програм та наданою квотою на мобільність для студентів Угорщини за програмами Erasmus. Незважаючи на те, що для проаналізованих університетів скорочення кількості учасників програм мобільності $\epsilon$ більш суттєвим, у порівнянні з іншими угорськими університетами, подібна спадаюча тенденція простежується у маситабах всієї країни. Основною метою дослідження є аналіз та систематизація основних бар'єрів поширення програм мобільності Erasmus, а також розробка дієвих механізмів їх усунення. Емпіричні дані для дослідження були отримані на основі анкетування 225 респондентів студентів Мішкольцького Університету, проведеного у 2016 роиі. Для аналізу отриманих даних авторами використано бінарну логістичну регресію. Емпіричні результати дослідження дали підстави виокремити фрактори, що стримують поширення програм мобільності серед ЗВО 
Z. Bartha, A. S. Gubik, G. Rethi. Management of Innovations in Hungarian HEls: Enhancing the Erasmus Mobility Programme

Угорщини, а саме: рівень інформованості студентів та викладачів про програми мобільності Erasmus; міжнародний досвід/обізнаність у мультикультурному середовищі; рівень володіння іноземною мовою; побоювання механізму безготівкових грошових переказів; рівень освіти. Здідно результатів проведеного дослідження авторами запропоновано шляхи подолання вищенаведених бар'єрів, а саме: налагодження комунікацій зі студентами з метою підвищення рівня їх поінформованості про можливості програми мобільності Erasmus; удосконалення послуг, що сприятимуть подоланню мовних перешкод та проблем процесу безготівкового перерахування коштів; ознайомлюючі міжнародні поїздки та літні школи, що можуть надати студентам міжнародний досвід. Автори зазначають, що запропоновані у рамках дослідження пропозиції, $\epsilon$ нескладними у реалізації, однак, їх імплементація може стримуватись браком фрінансових ресурсів в університетах, а також відсутністю чіткої стратегії їх розвитку та орієнтації на цілі програми Erasmus. Незважаючи на те, що опитування проведене серед студентів університету Мішкольия, автори наголошують на тому, що отримані висновки можуть бути використаними східноєвропейським університетам, метою яких $є$ активізація міжнародної студентської мобільності.

Ключові слова: Erasmus, інновації в освіті, управління освітою, академічна мобільність, студент.

Manuscript received: 16.12 .2018

(c) The author(s) 2019. This article is published with open access at Sumy State University. 